\title{
Fishery science: the study of fishery systems
}

\author{
Anthony T. Charles \\ Department of Finance and Management Science, Saint Mary's University, \\ Halifax, Nova Scotia B3H3C3 Canada.
}

Accepted May 3, 1995.

Charles A.T. Aquat. Living Resour., 1995, 8, 233-239.

\begin{abstract}
The pursuit of sustainable lisheries requires a broad vision of fishery science - as the scientilic study of fishery systems. This implies the incorporation into fishery science of research on fishery management, fishing processes, fisher behaviour and the human dynamics of fishery systems. Such research requires (a) more extensive multidisciplinary linkages, with an increased role for economic and social science research, and (b) more day-to-day linkages between people, namely those involved in fishery science and in management, together with fishery stakeholders. This paper reviews potential directions for fisheries research, and suggests a corresponding range of multidisciplinary research priorities, focused on analysis of: (a) the fishery management system, at both strategic and operational levels, (b) fisher behaviour and response to regulations, (c) "human dynamics" in fisheries, and (d) fishery systems modelling.
\end{abstract}

Keywords: Fishery systems, multidisciplinary approaches, fishery management system, human dynamics, fishery science, fisher behaviour, fishery systems modelling.

La science halieutique: l'étude des systèmes "pêche ".

Résumé

La poursuite de l'exploitation durable des pêcheries nécessite une vision élargie de la science halieutique - conçue comme l'étude scientifique des systèmes de pêche. Cela suppose la prise en compte dans l'halieutique de recherche sur la gestion des pêches, les techniques de pêche, les comportements des pêcheurs et les dynamiques sociales afférentes au système pêche. De telles recherches nécessitent à leur tour (a) un élargissement des liens entre les disciplines, où l'économie et les sciences sociales doivent tenir un rôle accru, et (b) davantage de relations au quotidien entre les acteurs, en particulier ceux impliqués dans l'ensemble des recherches halieutiques, les responsables de la gestion, ensemble avec les acteurs économiques du système productif. Cet article présente quelques orientations possibles pour la recherche halieutique, et suggère par rapport à celles-ci quelques priorités de recherche devant être développées en multidisciplinarité, portant sur l'analyse: (a) du système de régulation des pêcheries, à la fois au niveau stratégique et opérationnel, (b) des comportements des pêcheurs et leurs réponses face aux modes de régulation mis en place, (c) "les dynamiques humaines " dans les pêches, et (d) la modélisation des systèmes halieutiques.

Mots-clés : Système halieutique, approche multidisciplinaire, système de gestion des pêches, dynamique humaine, recherche halieutique, comportement des acteurs, modélisation des systèmes halieutiques. 


\section{INTRODUCTION}

The goal of "sustainable development" is rapidly becoming established globally. One might imagine that the fishery sector, with its long-standing awareness of sustainable yield concepts, might serve as a useful model of how other sectors of human endeavour might achieve sustainability. Yet in fact, many if not most fisheries are faced with serious ecological, economic and social problems - problems which can be traced back in large part to failures in management institutions, and in the related scientific processes (Charles, 1994).

In the search for sustainable fisheries, how can the nature and functioning of fishery science be improved? The key, it is argued here, is to view fishery science in a broad sense, as the integrated study of fishery systems, their structure and their dynamics. Therein lies the focus of this paper. The following section reviews proposed "new approaches" to fishery science, examining key research priorities and the challenges they pose. The third section reviews research themes and integrated modelling methods, oriented toward multidisciplinary views of fishery science. Conclusions are drawn in the final section.

\section{DEVELOPING A MULTIDISCIPLINARY FISHERY SCIENCE}

There are undoubtedly many views concerning prioritics for fisheries research. One such perspective has been provided by the Fisheries Resource Conservation Council (FRCC), an advisory body established by the Canadian government in 1993, with a membership of fishing industry participants and academics (including this author), as well as provincial and federal officials. The FRCC has a broad ongoing mandate to advise the government on fish stock harvesting levels and other fishery conservation issues in Atlantic Canada, through a process based on public consultations.

One aspect of the FRCC mandate is to provide advice on fishery research priorities. This responsibility led to a report to the Minister of Fisheries and Oceans (Fisheries Resource Conservation Council, 1994), in which the FRCC recommended a multidisciplinary and systems-oriented "new approach" for fishery research. The five elements of this are presented below, together with this author's comments on issues of implementation.

\section{Research process and structure}

"It is important that a multidisciplinary team approach be implemented in addressing fishery research questions - both in the laboratory and in the field."; (FRCC, 1994: p. 118)

Although increasing numbers of fishery researchers are interested in multidisciplinary fisheries research (e.g. see Durand et al., 1991), it has proven difficult in most cases to institutionalize such approaches. The key reason may be one of inertia, within fishery agencies and amongst researchers. Within government, the greatest change must come in enlarging economic, and particularly social science, research components (Andersen, 1978; Fricke, 1985; Pollnac and Littlefield, 1983; Pringle, 1985). For example, within the Canadian Department of Fisheries and Oceans (DFO), "research" tends to be viewed as the domain of natural scientists - not cconomists, managers or certainly social scientists, who are essentially nonexistent in government laboratories.

In terms of rescarch personnel, many of those trained within a particular discipline have a natural inclination to remain there, while those choosing to pursue multidisciplinary work face the task of "selling" their research as valid within the narrow confines of that original discipline. Attracting "new blood" with multidisciplinary training is difficult, given the discipline-based environment of most research centres, combined with the widespread phenomenon of cuts to governmental employment.

"It is also important that there be better integration and coordination in DFO Science lthe fishery research establishment] between regions, between the Science, and the Operations, Policy and Enforcement Sectors, and as well, between the Department and the fishing industry generally." (FRCC, 1994: p. 118)

Typically, separate entities within fishery agencies deal with the three activitics of (1) scientific research, (2) operational management and enforcement, and (3) economics and policy. A lack of strong connections between these may well lead to failures in the design and implementation of management measures. For example in Allantic Canada, DFO fishery economists frequently deal with major policy initiatives, often in the absence of substantive research. The introduction of Individual Transferable Quota (ITQ) systems is an example. If there had been more involvement by DFO Science and by social scientists in examining the implications of ITQs, and indeed the alternatives to ITQs, might it have been possible to minimize the problems that have occurred under such systems (e.g. dumping and discarding, as reported in Angel et al., 1994)? There has been some effort toward developing these linkages (e.g. Mahon, 1985), but much remains to be accomplished.

"It is important that a genuine thrust be made to give a more effective role in fishery science to those with practical experience and knowledge in the fishery, and the role must be rigorous and transparent." (FRCC, 1994: p. 118)

In the Canadian context, the vast majority of research has taken place within government (and universities); involvement of the fishing industry in this research, on a participatory basis, is a relatively new but growing trend. On the Atlantic coast, in particular, partnerships are now being 
institutionalized with the formation of the Fishermen and Scientists Research Society, an organization dedicated to conducting joint research and providing scientific training to fishers (King et al., 1994).

\section{Research priorities}

"It is important that a real move be made towards an ecosystem approach to fisheries management. The various bits and pieces of ecological knowledge must be reflected in a better understanding of the whole system. Thinking in terms of whole ecosystem must become an essential and integral part of day-today activities, not just for Science, but within the Department of Fisheries and Oceans generally." (FRCC, 1994: p. 118)

"It is important that scientists study fishing scientifically as a system and strive to better understand the relationship between fish (resource) and fishing (fishing practices, gear technology, capacity analysis, etc.). This must reflect the recognition that fishery science involves more than the natural sciences and that scientific research is a part of the development, implementation and evaluation of fishery management measures and economic policy tools." (FRCC, 1994: p. 1/8)

These two priority areas both involve a combination of disciplines. In the former case, the linkage may be most important between biology and oceanography (although certainly human sciences are also needed, since humans are part of the ecosystem). In the latter, where attention will be focused in the remainder of the paper, the key is a combination of biology, economics and social research.

It is worth noting that in combining the latter disciplines, the two subthemes of bio-economics and socioeconomics are of importance. Bioeconomic modelling is the combination of population dynamics and economics within a quantitative framework (e.g. Clark 1976, 1985), while fishery socioeconomics research has been more qualitative, linking social research (on such topics as distribution of income, work satisfaction and community welfare) with economic themes such as labour processes, costs and earnings (Charles, 1988; Charles et al., 1994). The first of these areas, bioeconomics, has become popular as a relatively straightforward means for biologists to incorporate economics into their analyses. On the other hand, socioeconomics has received little attention within fishery science - although this is likely to change as more integrated approaches emerge, and efforts are made (as will be discussed below) to develop quantitative fishery models incorporating socioeconomics.

\section{MULTIDISCIPLINARY RESEARCH THEMES}

Many research themes call out for a multidisciplinary and integrated approach, involving biological, economic, social and institutional analysis. For an extensive review of these themes in the context of fishery research worldwide, with a focus on smallscale fisheries, see the conference volumes of Durand et al. (1991). In this section, several such themes are described, highlighting research questions on fisheries management, fisher behaviour, human dynamics, and fishery systems modelling.

\section{Fishery management: strategic choices}

The first step in fishery management is the "strategic" choice of an overall framework. This leads to several basic questions requiring a broad integrated view of fishery science:

- What factors affect the choice of, or natural evolution of, an overall fishery management system? For example, consider the differences between management systems for lobster and groundfish fisheries in Atlantic Canada. The former exploits a basically sedentary species, with relatively clear geographical boundaries between fishing zones of neighbouring communities, and with a tradition of local-Jevel self-regulation through input (effort) control. On the other hand, groundfish are relatively migratory and the fishery is more sector-based than community-based. This has implications for the feasibility of management initiatives. For example, while those in the mobile groundfish trawler flect tend to support their management system based on output control (ITQs), the idea of imposing such a system in the lobster fishery is met by strong opposition - for example: "There has been a rumour in the past year of putting lobsters on a quota system which we are STRONGLY AGAINST. We feel the lobster industry is more easily regulated by effort controls..." (Nash, 1995).

- Related to the above, what factors make a management system acceptable to the various fishery participants, so they will "buy into" conservation and management? How can mechanisms be designed to involve stakeholders in decision making while simultaneously meeting legislated requirements for resource conservation?

- What are the implications of having management on a centralized or on a decentralized basis? Does this decision differ between small-scale community. centred fisheries and more "industrial" fisheries, which lack a community base?

- What are the implications of sector-based vs. community-based fishery management, i.e. managing components of the resource users, regardless of location (e.g. "those fishers who use fixed gear") or managing geographically, drawing on non-fishers as well as fishers (e.g. "those stakeholders in Southwest Nova Scotia")?

- What are the implications of placing fishery management in the hands of government (in pursuit of societal objectives), entirely privatized (and thus 
driven by private objectives), or based on an intermediate "property rights" or "co-management" scheme?

- What are the conservation, management and enforcement impacts of the three principal property rights options (Berkes, 1989): state property (collective resource ownership, pursuing societal objectives), market-based property (e.g. individual transferable quotas), and community-based property (fishers and/or communities regulating themselves on a collective basis)?

\section{Fishery management: operational choices}

On an operational level, medium-term decisions typically involve the selection of direct management measures, which might be described in the following typology of control:

\begin{tabular}{lll}
\hline $\begin{array}{l}\text { Input Controls } \\
\text { (Effort) }\end{array}$ & $\begin{array}{l}\text { Outputs Controls } \\
\text { (Catch) }\end{array}$ & $\begin{array}{l}\text { Controls On Fish } \\
\text { Characteristics }\end{array}$ \\
\hline $\begin{array}{l}\text { Fishing Effort } \\
\text { (\# of Boats) }\end{array}$ & $\begin{array}{l}\text { Total Allowable } \\
\text { Catch (TAC) }\end{array}$ & $\begin{array}{l}\text { Fishing Location } \\
\text { (Spawning Grounds) }\end{array}$ \\
$\begin{array}{l}\text { Fishing Effort } \\
\text { (Capacity/Boat) }\end{array}$ & Individual Quotas & Fishing Seuson \\
$\begin{array}{l}\text { Fishing Area/Boit } \\
\text { (e.g. TURFs) }\end{array}$ & Community Quotas & Gear Type \\
\hline
\end{tabular}

Rescarch involving scientific and management considerations might focus on the stages involved in operational management:

- As a first step, what are the conservation and manageability implications of each of input-based and output-based controls (limiting fishing effort or catch, respectively)?

- Secondly, what are the impacts of specific control measures, such as total allowable catches (TAC's), escapement targets, closed arcas or seasons, and mesh size restrictions?

- Thirdly, what are the desired levels of the chosen control measures - such as choices of this year's TAC (e.g. for cod), this year's carapace size (e.g. for lobster), or this year's escapement target (e.g. for salmon)?

- Finally, what would be the feasibility and effectiveness of indirect controls, such as royalties or landings taxes, to indirectly induce "desirable" behaviour by fishers?

\section{Fisher behaviour: response to regulation}

Surely one of the most fundamental lessons of fishery management is this: fishers respond to regulations. In recent years, it has been realized that good fishery management requires not only the setting and enforcing of regulations, but also the ability to predict fisher response to these regulations.
As Hilborn and Walters (1992; p. 104) point out, an absence of the latter "has led to management strategies and regulatory schemes that ignore the dynamic responses of fishermen to changes in stock size and to management itself. These responses can dampen or even reverse the intended effects of regulation...". The first step in this process lies in examining the objectives, behaviour and decision making mechanisms of those involved (Bailey et al., 1986; Healey, 1984; Lamson and Hanson, 1984; McCay, 1980; Opaluch and Bockstael, 1984; Wilen, 1979). This is followed by sludies of hehavioral response to specific control measures, and to law enforcement approaches in general.

Response to input controls. A number of examples from Canada's Atlantic fisheries illustrate the role of fisher response. For example, in the groundfishery, restrictions on vessel length, designed to limit capacity expansion, were met with the logical development of a wider vessel, so that capacity expanded nonetheless. Similarly, increases in the minimum legal mesh size on trawlers have led to increases in the use of other unregulated inputs, such as time spent fishing and the location of fishing. In the Canadian lobster fishery, limitations on the number of traps allowed per fisher induced changes in other inputs; this has led in some cases to increased use of labour (perhaps hauling traps more frequen(ly), or a change in the location of fishing (with increased effort on offshore areas, which previously had been subject to low levels of exploitation).

Response to output controls. Two general principles seem to apply with respect to output controls. First, any regulatory measure that implies the illegality or nonfeasibility of the catch mix (in terms of species, fish sizes or fish locations) available to the fisher creates an incentive to change that catch mix (legally or illegally). Second, the incentive to exceed catch controls rises as the controls are placed on a more and more individual basis, i.e. from global $\mathrm{TACs}$, to sector quotas (e.g. a quota for "fixed gear vessels of 45-65 feet in leng(h"), to individual quotas or trip limits. It appears in particular that dumping and discarding (whether this be lower-valued small fish of a target species, or unwanted fish of a different species) are particularly serious activitics under ITQs or trip limits.

Fishery law enforcement. The very "raison d'être" for fishery law enforcement lies in the realization that illegal fishing is a common response to a regulatory framework designed to limit fishing activities. Conversely, the effectiveness of fishery enforcement could be improved if the design of regulations were based on a concrete approach to predicting the resulting fisher response (e.g. Charles, 1993; Furlong, 1991; Sutinen and Andersen, 1985; Sutinen et al,, 1990). However, the topic deserves more attention than it has received to date, particularly as it becomes apparent that illegal fishing and misreporting of catch levels have caused serious errors in stock assessment and management (for example, in 
Atlantic Canadian groundfisheries, see Angel et al., 1994).

\section{Human dynamics}

An understanding of how fishing fleets, fishing effort, labour and capital change over time is essential to the study of fishery systems, their management and conservation.

Fleet Dynamics. One approach to fishery dynamics began with the classic work of Smith (1968), who modelled the joint dynamics of a fish population and fishing effort. This work sought to address the question of how fishers as a whole will vary effort over time, in response to economic conditions (profit levels, relative 10 opportunity costs). A second, more recent approach involves studies to better understand where and when fishers choose to operate; as Hilborn and Walters (1992) note, "it is foolish to study only the prey in the predator-prey system... it is equally important to monitor and understand basic processes that determine the dynamics of the predator - the fishermen".

Labour dynamics. Terkla et al. (1985) argue that in fishery systems, "understanding labour adjustment processes is likely to be crucial for implementing efficient and equitable management policy". There is considerable potential to accomplish this through a combination of socioeconomic analysis and quantitative modelling; see, for example, the empirical study by Panayotou and Panayotou (1986) on labour dynamics in Thailand fisheries. Modelling methods, based on a combination of bioeconomics and socioeconomics, will be discussed below.

Capital dynamics and capacity expansion. The phenomena of capacity expansion provides an excellent example of the need for a multidisciplinary view of fishery science; in the past, with fishery research focused on the fish, and economists focused on short-term problem solving, the dynamics of "behind the scenes" capacity expansion were not fully studied. Perhaps the most intriguing situation arises when apparent success in conservation leads to an initial increase in a formerly depleted fish stock. This induces increased fishing effort, temporary abovenormal profits, and increased investment, driven by the incentive of fishers to increase their share of fishery revenues. Accordingly, overall costs rise, rents dissipate, and political pressure mounts to allow even greater harvest levels, to maintain incomes. Since the fish stock has been "re-built", greater effort is possible for some time, without excessive depletion, thereby lulling the industry and the government into a false sense of security - until the expansion reaches a point where the stock declines and a "crisis" sets in.

This phenomenon has become well-known, having occurred in many fisheries of the world, including Canada's Pacific salmon fishery and Atlantic groundfish fishery (see, for example, Parsons, 1993).
However, the quantitative dynamics of capacity expansion are relatively unstudied, so that there remains considerable need for further research perhaps along the lines of empirical examples on fisher investment dynamics, such as Lane (1988) on trollers in the British Columbia salmon fishery, and Tettey and Griffin (1984) on investment patterns for American shrimp fisheries in the Gulf of Mexico.

\section{Modelling the fishery system}

While separate biological and economic analyses of fisheries have a lengthy history (e.g. Warming, 1911), efforts to develop integrated studies combining these aspects date from the middle of the 20th century (e.g. Schaefer 1957). This progressed further into dynamic analysis in the late 1960 's, notably with the models of Smith (1968).

Bioeconomic models. Dynamic modelling proceeded with development of "bioeconomic" models, notably by Clark (1976, 1985). These have captured considerable interest amongst both fishery biologists and fishery economists, since the approach is a natural one: link biological concepts (population dynamics, fish growth, etc.) and economic ones (such as profit functions, supply and demand), using mathematical modelling as a "glue". From a methodological perspective, bioeconomic modelling has enabled researchers to develop analyses with considerable intuitive appeal, capturing the dynamics of both fish and fleets. It has also provided a language which can help bridge the gap between biologists and economists working on common projects.

To date, the success of bioeconomic modelling has been largely as a conceptual tool, providing theoretical insights into the dynamic operation and management of fisheries. However, there is considerable potential to utilize the approach on case studies using simulation modelling (e.g. with FAO's BEAM IV software).

Bio-socio-economic models. The key idea of biosocio-economic modelling lies in combining, within an integrated, systematic framework, the quantitative approach of bioeconomic fishery modelling with the themes arising within fishery socioeconomics. Emphasis is placed on analyzing the human dynamics of fishers and fishing communities, based on predicted responses to changing fishery and external conditions; this contrasts with the more usual focus on dynamics of fishing vessels or hypothetical "fishing firms". The approach also explicitly incorporates the multiple objectives of society and of the fishery participants. Examples include the empirical simulation modelling work of Krauthamer et al. (1987) and the theoretical optimization study of Charles (1989), the latter involving analysis of joint fish and labour dynamics in a fishery system.

The bio-socio-economic framework serves to highlight the key information requirements needed to undertake integrated fishery studies (see, for example, 
Sivasubramaniam, 1993). In particular, to "fit" biosocio-economic models, one needs time series of data not always associated with the fishery itself - such as that on labour forces, labour participation rates and fishing community populations (e.g. Copes, 1983) as well as the more usual data on fish stock dynamics and cconomic parameters.

Other fishery management models. Complementing the biocconomic and bio-socio-economic approaches are other related methods to explore fishery policy options in light of management objectives and system hehaviour. For example, operations research provides a range of methods from lincar programming to risk analysis (e.g. Rodrigues, 1990), while "adaptive environmental assessment" (e.g. Walters, 1986) is a participatory process of computer simulation, used to study the effects of proposed management options on social, cconomic and biological indicators. While most such approaches focus on modelling the impacts of imposed management measures on the fishery, it is also important to understand how management agencies themselves interact with the fishing industry (e.g. Anderson, 1987). Within this context, the regulatory system (including scientific research, fishery managers, and the legislative framework) represents one part of a dynamic system alongside the fish, the fishers and the fishing communities.

\section{CONCIUSION}

This paper calls for a vision of fishery science as the inherently-multidisciplinary study of fishery systems. Within this vision, it is important to recognize the role within fishery agencies of economic and social science research, as well as participatory fisher-oriented research. Achieving this may well require changes to the structure of the fishery agency. Priority areats for fishery science should include analyses of (a) the management system (at both strategic and operational levels), (b) fisher behaviour, and in particular, response to regulations, (c) the human dynamics in fishery systems, and (d) integrated systems modelling approaches. Third, the above implies a corresponding need for an improved information base on the human side of the fishery system (FAO, 1985; Lamson and Reade, 1987).

Certainly, changes to the directions and priorities of fishery science will not in themselves result in sustainable fisheries. Yet when combined with changes to the institutional arrangements by which fisheries are managed, and the attitudes of those involved, there is hope to achieve a rather higher success rate than has been the case historically in the area of fishery sustainability.

\section{Acknowledgments}

Financial assistance provided by the Natural Sciences and Engineering Research Council of Canada, grant \#A6745, is gratefully acknowledged.

\section{REFERENCES}

Andersen R. 1978. The need for human sciences rescarch in Atlantic Coast fisheries. J. Fish. Res. Board Can. 35, 1031-1049.

Anderson L. G. 1987. A management agency perspective of the economics of fisheries regulation. Mar. Res. Econ.

4, 123-131.

Angel J. R., D. L. Burke, R. N. O'Boyle, F. G. Peacock, M. Sinclair, K. C. T. Zwanenburg 1994. Report of the Workshop on Scotia-Fundy Groundfish Management from 1977 to 1993. Can. Tech. Rep. Fish. Aquat. Sci. 1979, $175 \mathrm{p}$.

Bailey C., C. Harris, C. Heaton, R. Ladner 1986. Proceedings of the Workshop on Fisheries Sociology. Woods Hole Oceanographic Inst. Tech Report WHOI86-34.
Bcrkes F. (ed.), 1989. Common Property Resources: Ecology and Communit-Based Sustainable Development. Belhaven Press, London, U.K., 302 p.

Charles A. T. 1988. Fishery sociocconomics: A survey. Land Econ. 68, 276-295.

Charles A. T. 1989. Bio-socio-economic fishery models: Labour dynamics and multi-objective management. Can. J. Fish. Aquat. Sci. 46, 1313-1322.

Charles A. T. (ed.), 1993. Fishery Enforcement: Economic Analysis and Operational Models. Oceans Institute of Canada, Halifax, 74 p.

Charles A. T. 1994. Towards sustainability: The fishery experience. Ecol. Econ. 11, 201-211.

Charles A. T., T. R. Brainerd, A. Bcrmudez M., H. M. Montalvo, R. S. Pomeroy 1994. Fisheries Socioeconomics in the Developing World: Regional Assessments and an Annotated Bibliography. International Development Research Centre, Ottawa, Canada, 163 p. 
Clark C. W. 1976. Mathematical Bioeconomics: The Optimal Management of Renewable Resources. WileyInterscience, New York, U.S.A., 352 p.

Clark C. W. 1985. Biveconomic Modelling and Fisheries Management. Wiley-Interscience, New York, U.S.A., $291 \mathrm{p}$.

Copes P. 1983. Fisheries management on Canada's Atlantic coast: Economic factors and socio-political constraints. Can. J. Region. Sci. 6, 1-32.

Durand J. R., J. Lemoalle, J. Weber (eds.), 1991. Research and Small-Scale Fisheries. ORSTOM, Paris, France, $1441 \mathrm{p}$.

FAO 1985. Report of the Expert Consultation on the Acquisition of Socioeconomic Information in Fisheries. FAO Fish. Rep. No. 344.

Fisheries Resource Conservation Council 1994. Conservation: Stay the Course - Report to the Minister of Fisheries and Occans on 1995 Conservation Requirements for Atlantic Groundfish. FRCC 94,R4E, Minister of Supply \& Services, Ottawa, Canada, 138 p.

Fricke P. 1985. Use of sociological data in the allocation of common property resources. Mar. Policy 9, 39-52.

Furlong W. J. 1991. The deterrent effect of regulatory enforcement in the fishery. Land Econ. 67, 116-129.

Healey M. C. 1984. Multiattribute analysis and the concept of optimum yield. Can. J. Fish. Aquat. Sci. 41, 1393-1406.

Hilborn R., C. J. Walters 1992. Quantitative Fisheries Stock Assessment: Choice, Dynamics and Uncertainty. Chapman and Hall, New York, U.S.A., 570 p.

King P. A., S. G. Elsworth, R.F. Baker 1994. Partnerships - The route to better communication. In: Coastal Zone Canada '94, Cooperation in the Coastal Zone: Conference Proc. P. G. Wells, P. J. Ricketts eds. Coastal Zone Canada Association, Dartmouth, Canada, 596-611.

Krauthamer J. T., W. E. Grant, W. L. Griffen 1987. A sociobio-economic model: The Texas inshore shrimp fishery. Ecol. Model. 35, 275-307.

Lamson C., A. J. Hanson (eds.) 1984. Allantic Fisheries and Coastal Communities: Fisheries Decision-Making Case Studies. Dalhousie Ocean Studies Program, Halifax, Nova Scotia, 252 p.

Lamson C., J. G. Reade 1987. Atlantic Fisheries and Social Science: A Guide to Sources. Can. Tech. Rep. Fish. Aquat. Sci. 1549.

Lane D. E. 1988. Investment decision making by fishermen. Can. J. Fish. Aquat. Sci. 45, 782-796.

Mahon R. (Ed.) 1985. Towards the Inclusion of Fishery Interactions in Management Advice. Canadian Technical Report of Fisheries and Aquatic Sciences, No. 1347, Department of Fisheries and Oceans, Government of Canada, Ottawa.
McCay B. J. 1980. A fishermen's cooperative, limited: Indigenous resource management in a complex society. Anthro. Quarterly 53, 29-38.

Nash K. 1995. A Brief on the Lobster Fishery Area 27. Presented to the Fisheries Resource Conservation Council, February 1, 1995. Glace Bay Inshore Fishermen's Association, Glace Bay, Canada, 4 p.

Opaluch J. J., N. E. Bockstael 1984. Behavioral modelling and fisheries management. Mar. Res. Econ. 1, 105-115.

Panayotou T., D. Panayotou 1986. Occupational and geographical mobility in and out of Thai fisherics. FAO Fish. Tech. Paper 271, 77 p.

Parsons L. S. 1993. Management of Marine Fisheries in Canada. Can. Bull. Fish. Aquat. Sci. 225, 763 p.

Pollnac R. B., S. J. Littlefield 1983. Sociocultural aspects of fisheries management. Ocean Dev. Int. Law. 12, 209-246.

Pringle J, D. 1985. The human factor in fishery resource management. Can. J. Fish. Aquat. Sci. 42, 389-392.

Rodrigues A. G. (ed.) 1990. Operations Research and Management in Fishing. Kluwer Academic Pub., Dordrecht, Netherlands, $340 \mathrm{p}$.

Schaefer M. B. 1957. Some considerations of population dynamics and economics in relation to the management of marine fisheries. J. Fish. Res. Board Can. 14, 669-681.

Sivasubramaniam K. 1993. The biosociocconomic way: A new approach to management of small-scale fisheries in the Bay of Bengal region. Bay of Bengal News 52, 4-15.

Smith V. L. 1968. Economics of production from natural resources. Am. Econ. Rev. 58, 409-431.

Sutinen J. G., P. Andersen 1985. The economics of fisheries law enforcement. Land Econ. 61, 387-397.

Sutinen J. G., A. Rieser, J. R. Gauvin 1990. Measuring and explaining noncompliance in federally managed fisheries. Ocean Dev. Int. Law. 21, 335-372.

Terkla D. G., P. B. Doeringer, P. I. Moss 1985. Common property resource management with sticky labor: The effects of job attachment on fisheries management. Discussion Paper No. 108, Dept. of Econ., Boston Univ.

Tettey E. O., W. L. Griffin 1984. Investment in Gulf of Mexico shrimp vessels, 1965-77. Mar. Fish. Rev. 46, 49-52.

Walters C. J. 1986. Adaptive Management of Renewable Resources. MacMillan Publishing Company, New York, U.S.A., 374 p.

Warming J. 1911. Om grundrente af fiskegrunde (On rent of fishing grounds). National okonomisk Tidsskrift, 49, 499-505.

Wilen J. E. 1979. Fishermen behavior and the design of efficient fisheries regulation programs. J. Fish. Res. Board Can. 36, 855-858. 